\title{
Revenue Quality Analysis on Genetically Modified Listed Company Based on Factor Analysis
}

\author{
Chaoxin JI \\ School of Economics and Management, Hubei University of Automobile Technology, Shiyan 442002, \\ China \\ jichaoxin889@sina.com
}

Keywords: Earnings quality; the listed company; genetically modified (gm); Factor analysis.

\begin{abstract}
On the basis of the domestic and foreign research results on the quality of earnings, the comprehensive analysis of various kinds of earnings quality evaluation method, on the basis of proposed on earnings quality analysis of factor analysis, and from quantitative to gm unilaterally the earnings quality of listed companies is analyzed. In terms of quantitative analysis, build the genetically modified (gm) of the listed company earnings quality single index evaluation system, and on the basis of the use of principal component analysis method to construct genetically modified (gm) of the listed company earnings quality comprehensive evaluation index, using the factor analysis method to empirical analysis on earnings quality.
\end{abstract}

\section{Introduction}

In recent years, due in part to the exposure of a series of domestic and overseas financial fraud cases, analysts realize the importance of paying closer attention to enterprise revenue quality. In order to further analyze revenue quality, this paper will use genetically modified (GM) listed companies as a research object. Starting from the connotation of revenue quality, quantitative analysis is taken as evidence to construct revenue quality evaluation system by referring to many domestic and overseas published articles to explore the definition of revenue quality. Additionally, accounting software SPSS is also used to conduct analysis on GM listed companies.

\section{Relevant Issue of Revenue Quality}

It can be concluded from domestic and overseas research that analysis and evaluation of revenue quality covers a large range of aspects. The methods, models, and evaluation systems also vary. Meanwhile, scholars have not reached an agreement on the connotations, influence factors, and established evaluation systems of revenue quality.

\subsection{Relevant Definition of Revenue quality}

Revenue refers to accounting income that is confirmed according to accrual basis and matching principle in a certain accounting period, also known as accounting profit. It is significant evidence for evaluating business performance.

An essential connotation of quality is adaptability, i.e. the standard made for management and the control of quality. It is set by people on the basis of existing knowledge to request for various attributes of product in the processing (manpower supply) so as to ensure adaptability.

In this paper, revenue quality is defined in terms of quality and quantity. From the perspective of the amount of earning information, quality is regarded as the matching level of earning information and actual information; quantity of earning attaches importance on the amount to reflect the measurement of enterprise income and earning capability.

\subsection{Quantitative Analysis of Revenue quality}

(1) Earning Persistence Analysis

Firstly, the ratio of main business, as vital indicator of measuring revenue quality should be considered into the analysis. The larger the index is, the stronger the income persistence is and the better the revenue quality is. For analyzing this indicator's variation trend, figures of recent years should be selected to make comparison. 
Secondly, after deducting non-recurrent item, the ratio of left-over net profit to of the original net profit is utilized to analyze. Enterprise transaction can be divided into current account and non-recurrent item according to frequency. Profit in current account is called recurring revenue which is the core of profit. As recurring gain and loss is persistent, this index can accurately make judgment and prediction on surplus capacity of a company in future and sustainable development level of enterprises concerned. The larger the proportion of non-recurring gain and loss of an enterprise to net profit, the lower revenue quality is.

(2) Growth Analysis of Profit

First of all, profit growth rate of main business is selected to conduct analysis, which is important measurement for judging whether revenue quality is equipped with growth rate or not. In general, the bigger this index is, the stronger the income persistence is and the better the revenue quality is. Secondly, growth rate of operating cash can be utilized for analysis. Growth of main business should be synchronously accompanied with increase of operating cash and otherwise, cash guarantee of profit made by main business is poor and consequently revenue quality is low.

(3) Analysis of Profit's Cash Protection

Profit's cash protection refers to the capability of changing accounting profit generated in business operation to cash that can be freely governed by enterprises. Sales cash ratio reflects the amount of returned money per sales revenue thus it can be considered into the analysis. The larger the ratio is, the more the returned cash is. The larger the profitability ratio is and the better the revenue quality is. Meanwhile, when this ratio drops, investors should pay closer attention not only to whether the operating cash flow reduces or not but also to the possibility of inflate revenue which declines revenue quality. Secondly, operating cash ratio of business profit reflects the actual cash proportion in profit of enterprise's unit sales in business and can be also considered as a key factor into analysis. If the value is less than 1 , cash will still be short even if the company is making profit.

\section{Construction of Revenue Quality Evaluation Model}

\subsection{Revenue quality Evaluation of Listed Company Based on Factor Analysis}

Factor analysis is equipped with many unique advantages. For example, weighting coefficient is objective and can furthest use raw data. In addition, SPSS is relied on to make application easier.

\subsection{Construction of Factor Analysis Model}

(1) Index pre-treatment: Due to influence of different dimensions, it should conduct pretreatment for original variable firstly when applying factor to analyze model and two steps should be mainly included.

As no inverse index can be found in established index system, it only needs to standardize raw data, eliminate dimension factor and make data analyzable. Standardization transformation is shown as follows and the mean after transformation is 0 and variance is 1 .

$$
\mathrm{X}_{\mathrm{ij}}=\mathrm{Y}_{\mathrm{ij}}-\mathrm{EY}_{\mathrm{j}} / \sqrt{\mathrm{DY}_{\mathrm{j}}} \quad i=1,2,3, \ldots . . n, j=1,2, \ldots \ldots, n
$$

where

$$
\mathrm{EY}_{\mathrm{ij}}=\frac{1}{\mathrm{n}} \sum_{i=1}^{n} Y_{i j}, \mathrm{DY}_{\mathrm{j}}=\frac{1}{\mathrm{n}-1} \sum_{i=1}^{n}\left(Y_{i j}-E Y_{j}\right)^{2}
$$

(2) Establishment of Factor Analysis Model:

$$
\left\{\begin{array}{c}
X_{1}=a_{11} F_{1}+a_{12} F_{2}+\cdots+a_{1 m} F_{m}+\xi_{1} \\
X_{2}=a_{21} F_{1}+a_{22} F_{2}+\cdots+a_{2 m} F_{m}+\xi_{2} \\
\cdots \cdots+a_{n m} F_{m}+\xi_{n}
\end{array}\right.
$$

It is denoted as $\mathrm{X}=\mathrm{AF}+\xi$, where $\mathrm{X}=\left(\mathrm{X}_{1}, \mathrm{X}_{2}, \ldots, \mathrm{X}_{\mathrm{n}}\right)^{\prime}$ is vector composed by $\mathrm{n}$ indexes and $\mathrm{F}$ is a common factor of index, $\mathrm{F}=\left(\mathrm{F}_{1}, \mathrm{~F}_{2}, \ldots, \mathrm{F}_{\mathrm{m}}\right)^{\prime}, \mathrm{m} \leqq \mathrm{n}$, matrix $\mathrm{A}$ is a factor loading matrix.

(3) Examination of Condition for Factor Analysis 
(4)Determination of Factor Loading. Principal component analysis is chosen to solve factor loading of sample correlation matrix, and meanwhile the eigenvalue and eigenvector, SPSS 16.0 is applied. Total variable is obtained according to eigenvalue and top $\mathrm{k}$ eigenvalues and relevant vectors will be selected.

(5)Orthogonal mapping is conducted for factor matrix, i.e. orthogonal mapping of maximum variance. In this way, common factor is more explanatory and significance is clearer.

(6) Calculate the core of various factors. After factor variables and maximum variance rotate, the variable is further determined so that sample can obtain data of various factors, that is, factor score.

$$
F_{j}=\beta_{j 1} X_{1}+\beta_{j 2} X_{2}+\ldots+\beta_{j P} X_{P}, j=1,2, \ldots, m
$$

(7) Comprehensive Factor Score. Weighted summation is made by adding up the score of single factor and the weight of various factors, which serves as the synthesis score. The weight of various factors is corresponding to their own variance contribution rates.

\subsection{Construction of Revenue Quality Index}

$$
\mathrm{F}=\mathrm{W}_{1} \mathrm{~F}_{1}+\mathrm{W}_{2} \mathrm{~F}_{2}+\ldots+\mathrm{W}_{\mathrm{k}} \mathrm{F}_{\mathrm{k}}
$$

Based on the quantitative analysis of earnings, relevant indexes are selected as variables in the research. See details about indexes in Table 2.1. The indexes are referred from Analysis on Revenue Quality of China's Listed Companies issued by Gai Di and Wu Zhonghua (2007) in Acadamic Journal of Yunnan University of Finance and Economics.

\begin{tabular}{|c|c|c|c|}
\hline Code & Index & Formula & Implication \\
\hline $\mathrm{X} 1$ & $\begin{array}{l}\text { Contribution rate } \\
\text { of main business } \\
\text { profit }\end{array}$ & $\begin{array}{l}\text { Main business } \\
\text { profit/total profit }\end{array}$ & $\begin{array}{l}\text { This proportion and its fluctuation reflect the operation } \\
\text { performance of the company's major works and its } \\
\text { long-term profitability. The stronger a company's core } \\
\text { competence is and the closer the index value is to 1, then } \\
\text { the better the sustainability of profits and the higher } \\
\text { revenue quality is. }\end{array}$ \\
\hline $\mathrm{X} 2$ & $\begin{array}{l}\text { The net profit } \\
\text { with } \\
\text { non-recurring } \\
\text { profit and loss } \\
\text { deducted/net } \\
\text { profit }\end{array}$ & $\begin{array}{l}\text { The net profit with } \\
\text { non-recurring profit and } \\
\text { loss deducted/net profit }\end{array}$ & $\begin{array}{l}\text { Recurrent profit and loss is a company's core earnings and } \\
\text { is sustainable. Investors can predict a company's } \\
\text { profitability in the future and judge its sustainable } \\
\text { developmental level based on it. The ratio of } \\
\text { non-recurring profit and loss to net profit is an inverse } \\
\text { index. }\end{array}$ \\
\hline X3 & $\begin{array}{l}\text { Growth rate of } \\
\text { main business }\end{array}$ & $\begin{array}{l}\text { Increased main business } \\
\text { profit in report } \\
\text { period/the amount of } \\
\text { main business profit in } \\
\text { base period }\end{array}$ & $\begin{array}{l}\text { In general, the larger index value means stronger growth } \\
\text { of earnings and higher revenue quality. }\end{array}$ \\
\hline $\mathrm{X} 4$ & $\begin{array}{l}\text { Growth rate of } \\
\text { operating cash }\end{array}$ & $\begin{array}{l}\text { Increased net inflow of } \\
\text { operating cash in report } \\
\text { period/net flow of } \\
\text { operating cash in base } \\
\text { period }\end{array}$ & $\begin{array}{l}\text { The growth of main business and operating cash flow } \\
\text { shall be synchronized; otherwise, the cash protection of } \\
\text { main business profit will be poor, naturally leading to low } \\
\text { revenue quality. }\end{array}$ \\
\hline X5 & Sales cash ratio & $\begin{array}{l}\text { Net cash flow of } \\
\text { operating cash/business } \\
\text { income }\end{array}$ & $\begin{array}{l}\text { It reflects the returned money of effective sale a company } \\
\text { achieves; the larger the value and the more the returned } \\
\text { money are, the stronger the probability and the better } \\
\text { revenue quality are. }\end{array}$ \\
\hline X6 & $\begin{array}{l}\text { Operating cash } \\
\text { ratio of business } \\
\text { profit }\end{array}$ & $\begin{array}{l}\text { Net flow of business } \\
\text { cash/business profit }\end{array}$ & $\begin{array}{l}\text { It reflects the profit of this enterprise in its operating } \\
\text { activities and the actual cash collected in this report; if the } \\
\text { ratio is smaller than } 1 \text {, the company has to be prepared for } \\
\text { financial risk of running out of cash. Operating cash flow } \\
\text { is the practical capital generated in business operation, } \\
\text { and it can accurately explain a company's revenue quality. } \\
\text { If the ratio is smaller than it suggests that there are }\end{array}$ \\
\hline $\mathrm{X} 7$ & Profit cash ratio & $\begin{array}{l}\text { Net cash flow of } \\
\text { business activities/net } \\
\text { profit }\end{array}$ & $\begin{array}{l}\text { unattainable cash earnings in the net profit in report } \\
\text { period; if the ratio is smaller than } 1 \text { all the time and even } \\
\text { negative, then the company's revenue quality is poor and } \\
\text { can even result in bankruptcy. }\end{array}$ \\
\hline
\end{tabular}

Table 1 Detailed Index 


\section{Empirical Analysis of Factor Analysis}

Twenty-one listed companies on transgenosis in 2015 were taken as samples (ST Company is excluded). According to annual report, the primitive matrix is $\mathrm{X}=\left(x_{i j}\right)_{21 * 13}$ and corresponding results are concluded with the statistical software SPSS.

Table 2 Bartlett's Test of Sphericity and KMO Test (KMO and Bartlett's Test)

\begin{tabular}{ccc}
\hline Kaiser-Meyer-Olkin Measure of Sampling Adequacy. & .589 \\
\hline Bartlett's Test of Sphericity & Approx. Chi-Square & 155.663 \\
& df & 21 \\
& Sig. & .000 \\
\hline
\end{tabular}

Table 3 Correlative Coefficient Matrix (Correlation Matrix)

\begin{tabular}{ccccccccc}
\hline & & $\mathrm{x} 1$ & $\mathrm{x} 2$ & $\mathrm{x} 3$ & $\mathrm{x} 4$ & $\mathrm{x} 5$ & $\mathrm{x} 6$ & $\mathrm{x} 7$ \\
\hline \multirow{6}{*}{ Correlation } & $\mathrm{x} 1$ & 1.000 & .744 & .162 & .246 & .154 & .590 & .593 \\
& $\mathrm{x} 2$ & .744 & 1.000 & .205 & .304 & .158 & .266 & .269 \\
& $\mathrm{x} 3$ & .162 & .205 & 1.000 & .254 & .674 & -.115 & -.115 \\
& $\mathrm{x} 4$ & .246 & .304 & .254 & 1.000 & .068 & -.024 & -.023 \\
& $\mathrm{x} 5$ & .154 & .158 & .674 & .068 & 1.000 & .200 & .200 \\
& $\mathrm{x} 6$ & .590 & .266 & -.115 & -.024 & .200 & 1.000 & .999 \\
& $\mathrm{x} 7$ & .593 & .269 & -.115 & -.023 & .200 & .999 & 1.000 \\
\hline
\end{tabular}

Table 4 Total Variance Explained

\begin{tabular}{|c|c|c|c|c|c|c|c|c|c|}
\hline \multirow[b]{2}{*}{ Component } & \multicolumn{3}{|c|}{ Initial Eigenvalues } & \multicolumn{3}{|c|}{$\begin{array}{c}\text { Extraction Sums of Squared } \\
\text { Loadings }\end{array}$} & \multicolumn{3}{|c|}{$\begin{array}{c}\text { Rotation Sums of Squared } \\
\text { Loadings }\end{array}$} \\
\hline & Total & $\begin{array}{c}\% \text { of } \\
\text { Variance }\end{array}$ & $\begin{array}{c}\text { Cumulative } \\
\%\end{array}$ & Total & $\begin{array}{c}\% \text { of } \\
\text { Variance }\end{array}$ & $\begin{array}{c}\text { Cumulative } \\
\%\end{array}$ & Total & $\begin{array}{c}\% \text { of } \\
\text { Variance }\end{array}$ & $\begin{array}{c}\text { Cumulative } \\
\%\end{array}$ \\
\hline 1 & 2.890 & 41.282 & 41.282 & 2.890 & 41.282 & 41.282 & 2.494 & 35.630 & 35.630 \\
\hline 2 & 1.790 & 25.567 & 66.849 & 1.790 & 25.567 & 66.849 & 1.726 & 24.652 & 60.282 \\
\hline 3 & 1.212 & 17.308 & 84.157 & 1.212 & 17.308 & 84.157 & 1.671 & 23.875 & 84.157 \\
\hline 4 & .691 & 9.869 & 94.025 & & & & & & \\
\hline 5 & .271 & 3.876 & 97.901 & & & & & & \\
\hline 6 & .146 & 2.090 & 99.992 & & & & & & \\
\hline 7 & .001 & .008 & 100.000 & & & & & & \\
\hline
\end{tabular}

Extraction Method: Principal Component Analysis. 


\begin{tabular}{cccc}
\hline & & Component & \\
\hline y1 & 1 & 2 & 3 \\
y2 & .175 & .342 & -.052 \\
y3 & .012 & .480 & -.060 \\
y4 & -.106 & .057 & .528 \\
y5 & -.189 & .505 & -.046 \\
y6 & .090 & -.177 & .588 \\
y7 & .418 & -.114 & .004 \\
\hline
\end{tabular}

Extraction Method: Principal Component Analysis; Rotation Method: Varimax with Kaiser Normalization; Component Scores.

Table 6 Factor, Synthesis Score of Factor and Ranking

\begin{tabular}{|c|c|c|c|c|c|c|c|c|}
\hline \multirow{2}{*}{ Code } & \multicolumn{2}{|l|}{$\mathrm{F} 1$} & \multicolumn{2}{|l|}{ F2 } & \multicolumn{2}{|l|}{ F3 } & \multicolumn{2}{|l|}{ Synthesis } \\
\hline & Score & Ranking & Score & Ranking & Score & Ranking & Score & Ranking \\
\hline 600597 & -0.376376 & 15 & 1.84224266 & 1 & -0.5562253 & 20 & 0.32135087 & 4 \\
\hline 000375 & -0.755256 & 20 & -2.8033704 & 21 & -0.4308325 & 13 & -0.7939481 & 21 \\
\hline 600778 & 0.13290125 & 6 & -1.6977154 & 20 & -0.4337559 & 14 & -0.52208 & 20 \\
\hline 002100 & -0.1327198 & 8 & 0.21167354 & 10 & -0.2881466 & 10 & -0.0166132 & 11 \\
\hline 000713 & 0.26814142 & 5 & -0.3648329 & 17 & -0.5303882 & 18 & -0.2165688 & 15 \\
\hline 002041 & -0.2555533 & 13 & 0.12095452 & 13 & 0.19525836 & 4 & 0.07643564 & 7 \\
\hline 600371 & 4.00653622 & 1 & 0.59893755 & 3 & -0.3804385 & 11 & 0.05682039 & 1 \\
\hline 000998 & -0.4219985 & 17 & 0.40563909 & 7 & -0.0232364 & 7 & 0.09445047 & 8 \\
\hline 000796 & -0.3189565 & 14 & 0.09613169 & 14 & 0.00988731 & 6 & 0.02605898 & 9 \\
\hline 600755 & 0.34014956 & 3 & -0.6614792 & 18 & -0.0596869 & 8 & -0.1773181 & 13 \\
\hline 600108 & -0.3798279 & 16 & 0.14554452 & 12 & -0.4494855 & 15 & -0.071435 & 17 \\
\hline 600638 & -0.1988196 & 10 & 0.15079834 & 11 & 0.49082919 & 3 & 0.15436028 & 5 \\
\hline 000407 & -0.2166476 & 11 & 0.35760305 & 9 & -0.6262764 & 21 & -0.0613672 & 16 \\
\hline 002170 & -0.1678789 & 9 & 0.36283944 & 8 & -0.3860571 & 12 & -0.0027239 & 10 \\
\hline 600438 & -0.0257674 & 7 & 0.54064189 & 4 & -0.5123812 & 16 & 0.01094802 & 6 \\
\hline 600596 & -0.6593301 & 19 & 0.45353331 & 6 & -0.5189011 & 17 & -0.0120826 & 19 \\
\hline 000565 & -0.5743957 & 18 & 0.07351939 & 15 & -0.0989965 & 9 & -0.0055114 & 18 \\
\hline 002385 & -0.2374064 & 12 & 0.45851641 & 5 & -0.5468173 & 19 & -0.0175192 & 14 \\
\hline 600354 & 0.66371627 & 2 & -1.3858655 & 19 & 0.15117522 & 5 & -0.3055505 & 12 \\
\hline 000166 & 0.32857008 & 4 & -0.2160494 & 16 & 3.98974635 & 1 & 0.89929145 & 2 \\
\hline 300381 & -1.019081 & 21 & 1.31073741 & 2 & 1.00472904 & 2 & 0.56300205 & 3 \\
\hline
\end{tabular}




\section{Analysis}

\subsection{Empirical Analysis}

Table 3.1 shows that sample data can be used for factor analysis; Table 3.2 indicates the correlation among 7 indexes; Table 3.3 manifests that extracting three factor numbers is the most appropriate, as the first factor is cash protection factor, the second is sustainability factor and the third is growth factor; from Table 3.5, it can be seen that WanXiang Doneed Co., Ltd. (600371), Dunhuang Seed Industry Co., Ltd (600354) and Xiamen International Trade Group Corp. Ltd. (600755) are the top three for the score of factor F1, which is the cash protection factor of earnings; while Guangdong VTR Bio-Tech Co., Ltd. (300381), Luoniushan Co., Ltd. (00735) and Wynca Co., Ltd (000407) are last three companies. On the whole, these transgenosis listed companies in 2015 are supposed to strengthen their cashability of accounting income, as the higher cashability means a higher business accounting income.

The score of factor F2, revenue sustainability factor, for companies respectively are: Bright Dairy (600579) gets 1.8422, Guangdong VTR Bio-Tech Co., Ltd. (300381) obtains 1.3107 and Wanxiang gets 0.5989 . It can be seen that the core competitiveness of those companies' main business remained to be improved so that the proportion of main business' profit in total profit can be enhanced. Recurrent pro fit and loss is a sustainable and core earning for companies, since investors can predict companies' profitability in the future and judge their sustainable development based on it so as to make scientific and rational investment decision.

As for F3, the growth factor of revenue, among 21 listed companies, Shenwan Hongyuan Securities (000166) gets 3.9897, Guangdong VTR Bio-Tech Co., Ltd. (300381) obtains 1.0047, Xin Huang Pu (300381) gets 0.4908 , as a result, transgenosis listed companies have to pay closer attention to the growth rate of main business profit, since a company's profit growth will be stronger and revenue quality will be higher as this index goes larger.

As for the synthesis score, WanXiang Doneed Co., Ltd. (600371) ranks at the top resulted from being at the top of the ranking of profit cash protection; besides, earnings growth factor ranks 11, which has a quite large impact on the synthesis ranking. It can be seen that WanXiang Doneed Co., Ltd. has to strength the competitiveness of its core business, increase its investment in core business to let core business income have a stronger growth property. The second company is Shenwan Hongyuan (0001666). Although the revenue's cash protection factor and growth factor are quite influential, the sustainability of the company's revenue remains to be improved. The third is Guangdong VTR Bio-Tech Co., Ltd. (300381). This company ranks second for both its scores of revenue sustainability factor and growth factor, while the score of revenue's cash protection factor ranks 21 . It can be observed that this company has to improve its cashability of accounting income.

\subsection{Conclusion of Empirical Analysis}

Based on the studies of accounting revenue quality by scholars at home and abroad, a quality analysis and evaluation system for listed company's accounting income is preliminarily established in this paper, and conclusion is draw as follows:

Firstly, the quantity and its interior quality these two aspects should be considered when corresponding analysis and evaluation are being carried out on revenue quality of a certain company. In other word, the enterprise income of listed companies with investment value should be qualified in both quantity and quality.

Secondly, as the accounting revenue quality is affected by multiple factors, it shows various kinds of characteristics. Multiple indexes offset the isolationism of evaluating accounting revenue quality by a single index. With a comprehensive assessment of extensive evaluation indexes, EQI is more comprehensive and accurate in assessing the accounting revenue quality, so that listed companies can be supervised comprehensively in multiple levels and resource allocation in capital market will also be more effective.

Thirdly, the correct way of comprehensively analyzing and evaluating the revenue quality of listed companies is still an issue to be solved. For example, a large amount of data analysis is unable to accurately reflect revenue quality, and that's due to numerous influential factors which can't be expressed by data. As a result, additionally, qualitative and quantitative analysis should be combined. 
A favorable revenue quality should satisfy three requirements: sufficient cash protection, revenue of sustainability, and growth ability; however, a good revenue quality is not limited to these three conditions.

\section{Enlightenment and Suggestions}

\subsection{Government's Macroscopic Measures}

(1) Strictly carry out Accounting Law to rationally control profit operation behaviors;

The new Accounting Law emphasizes normalization and supervision strength of accounting behavior, endows the Ministry of Finance with supervision rights besides sticking to non-governmental audit. As a result, the implementation of new Accounting Law is in favor of correctly analyzing revenue quality of listed companies and also improving it under the impact of external pressures.

(2) Complete stock listing and delisting System and develop the resource allocation function of stock market

If listed companies pay too much attention to profitability, which can easily lead to profit manipulation. An evaluation system laying equal stress on profitability and revenue quality of listed companies should be established with revenue quality index brought in as an index for evaluating stock listing and delisting. Relevant systems should be also improved as to fully give play to the resource allocation function of stock market. By doing these above, listed company shall be driven to enhance revenue quality and promote virtuous circle of stock market.

(3) Rigorously control the audit of accounting policy alternative

Although the space for manipulating profit has been compressed by regulations, supervision department will also rigorously control the alternative audit policy of accounting to embrace challenges when relevant governmental departments stress self-discipline.

(4) Promote integrity education

Matters such as counterfeiting profit resulted from declining moral standard happen all the time and accounting is faced with "credit crisis", thus, it is is urgent to carried out integrity education.

\subsection{Measures for Listed Companies}

(1) Highlight their main business and maintain a lasting profitability

To enhance revenue quality, main business has to be strategically highlighted in company operation due to limited resources.

(2) Enhance the Efficiency and Benefit of Enterprise Assets

Raising profit level willfully requires a company to conduct self-digestion of the previous manipulation during a period in the future, which might lead to a situation of "discounting" future benefits and a large amount of non-performing loan.

(3) Adopt Relatively Steady Accounting Policy

A steady accounting policy can improve revenue quality, making paper profit more conform to actual business performance. Sticking to carrying out prudence concept is an inevitable requirement for preventing operational risk and maintaining a stable operation.

\section{References}

[1]. Yang Qiong. Evaluation Research on Accounting Revenue Quality of China's Listed Companies. Paper Database from Excellent Masters and Doctors in CNKI.

[2]. Chu Yijun. Wang Anwu. Revenue Quality Analysis of Listed Companies. Accounting Research 2000 (9).

[3]. Ma Jia. Enterprise Revenue Quality and Its Evaluation System. China Business \& Trade, 2010.

[4]. Wei Mingsheng. Empirical Study on Revenue Quality of Listed Companies in Guangxi. Guangxi Social Science, 2013.

[5]. Zhonghua Accountant Website: http://www.chinaacc.com/web/zyssfg_tdzzs. 
[6]. Royal Flush Financial Website: http://stock.10jqka.com.cn/20150205/c570587098.shtml.

[7]. East Money Net: http://stock.eastmoney.com.

[8]. Liu Hongwei. Research on the Evaluation System of the Revenue Quality of Listed Companies in China. Chinese Industrial Economics, 2011. 